\title{
Rotace horní části těla při golfovém švihu u elitních hráčů
}

\section{Rotation of a upper body during the golf swing with elite players}

\author{
Tomáš Gryc, František Zahálka, Tomášs Malý
}

\author{
Laboratoř sportovní motoriky, Fakulta tělesné výchovy a sportu Univerzity Karlovy \\ v Praze
}

\begin{abstract}
Abstrakt
Při golfovém švihu se zapojuji všechny tělni segmenty a je tak považován za jeden z nejkomplexnějšich pohybů ve sportu. Cílem studie bylo určit u zvolených kinematických parametrů pohybu pánve a segmentủ horni části těla (rotace ramen, rotace boků, X-faktor, natažení X-faktoru), které ovlivňují rychlost hlavy hole při kontaktu s mićkem u elitnich hráćů golfu. Pro utvořeni modelu horní části těla bylo použito šest aktivních bodů a jejich poloha v průběhu měrení byla snímána 3D kinematickým analyzátorem CODA Motion System. Pro určení stability provedení byl použit variační koeficient a pro statistické hodnocení vztahu mezi kinematickými a časovými parametry a rychlosti hlavy hole při kontaktu s míčkem byl použit Pearsonův korelační koeficient. Byla zjištěna vysoká interindividuální stabilita provedení, predevším u parametrů maximální rotace ramen v nápřahu a rychlost hlavy hole v okamžiku kontaktu s míčem. Při vztahové analýze mezi rychlostí hlavy hole $v$ okamžiku kontaktu s mičkem a sledovanými kinematickými parametry pohybu horní části těla byl nalezen vysoký vztah pouze s parametrem natažení X-faktoru.
\end{abstract}

\begin{abstract}
When the golf swing is involving all body segments and is thus considered as one of the most complex of sports motions. The aim of this study was to determine the selected kinematic parameters of movement of pelvic and segments of the upper body (shoulder rotation, hip rotation, X-Factor, stretch X-Factor) that affect the club head speed at ball contact in elite golfers. To build the upper body segment model were used spots and their position during the measurement was scanned by 3D kinematic analyzer CODA Motion System. To determine the interindividual stability of performance the coefficient of variation was used and for statistical analysis of the relationship between kinematic and temporal parameters and the club head speed at ball contact the Pearson's correlation coefficient was used. We found a high interindividual stability in maximized shoulders rotation and club head speed at ball contact parameters. When analyzing relationship between the club head speed at ball contact and the observed kinematic parameters of the movement of the upper body only a high relationship with the stretch $X$-factor parameter was found.
\end{abstract}

Klíčová slova: Golf, X-faktor, rychlost hlavy hole, kinematická analýza

Key-words: Golf, X-factor, club head speed, kinematic analyze

Tento př́spěvek vznikl v rámci Výzkumného záméru MŠMT ČR MSM 0021620864, s podporou projektu SVV 2013 267603, PRVOUK 038 a GAČR P407/11/P784.

\section{ÚVOD}

Při golfovém švihu se zapojují všechny tělní segmenty a je tak považován za jeden z nejkomplexnějších pohybů ve sportu, kde hlavní roli hraje zvládnutí a opakovatelnost techniky odpalu. Cílem hráče je dosáhnout správného nastavení hlavy hole a její maximální rychlosti v okamžiku kontaktu s míčkem pro dosažení požadovaného směru a vzdálenosti letu míče jako hlavních determinantů výkonu (Cochran \& Stobbs, 1968). Zlepšení výkonu při odpalech je hlavním cílem většiny golfistů. Vyprodukovaná energie v průběhu golfového švihu je hlavním determinantem výsledné vzdálenosti letu míče a jako její indikátor se použivá rychlost hlavy hole při kontaktu s míčkem (Meister et al., 2006; Ball \& Best, 2007). Cooper and Mather (1994) uvádějí, že profesionální hráči golfu dokáži maximálně zrychlit hlavu hole až v momentě kontaktu hlavy hole s míčkem, 
zatímco hráči s nízkým hendikepem (hendikep označuje výkonnost u amatérských hráčů golfu - čím nižší hendikep, tím lepší výkonnost) ještě před kontaktem s míčkem a hráči s vysokým hendikepem již v průběhu švihu.

Snahou při zvyšování efektivity golfového švihu je dosáhnout optimální pozice těla a hole v průběhu a ve vrcholu nápřahu pro dosažení maximální rychlosti hlavy hole při švihu (Adlington, 1996; Hume, Keogh, \& Reid, 2005). Rotace horní části těla byla identifikována jako klíčová složka ovlivňující produkci energie, kdy bylo zjištěno, že v průběhu nápřahu se ramena hráče otáčejí více než boky (Myers et al., 2008). Některé studie, realizované na elitních hráčích, zdůrazňují důležitost relativní a absolutní rotace pánve a horní části těla při golfovém švihu (Cheetham, Martin, Mottram, \& Laurent, 2000; Cochran \& Stobbs, 1996; Hume, et al., 2005; Zheng, Barrentine, Fleisig, \& Andrews, 2008; McLean, 1992). Úhlový rozdíl mezi otočením ramen a boků ve vrcholu nápřahu se v golfu označuje jako X-faktor a jeho vlivem na rychlost hlavy hole při kontaktu s míčkem se zabývaly mnohé studie (Lindsay \& Horton 2002; Bechler, Jobe, Pink, Perry, \& Ruwe, 1995). Bylo zjištěno, že úhlový rozdíl mezi otočením ramen a boků ve vrcholu nápřahu byl vyšší u profesionálních hráčů golfu (McLean, 1992) i u amatérských golfistů s vysokou rychlostí míčku po odpalu (Myers et al., 2008). Okamžik těsně před vrcholkem nápřahu, kdy rotace boků začíná švih k míči a dochází tak ke zvětšení X-faktoru, je označován jako Stretch X-factor (Cheetham et al., 2000; Myers et al., 2008), neboli natažení X-faktoru. Opačný rotační pohyb boků proti rotaci ramen může zvýšit úhlový rozdíl mezi rameny a boky, což má využití při snaze o dosažení delší vzdálenosti letu míče.

Z výše uvedených zákonitostí pohybu ramen a boků při golfovém švihu předpokládáme kladný vztah mezi délkou fáze „natažení X-faktoru“, charakterizovanou jako časový úsek mezi okamžikem počátek rotace boků k cíli a vrchol nápřahu, na výslednou rychlost hlavy hole v okamžiku kontaktu s míčkem.

Cílem studie je určit kinematické parametry pohybu pánve a segmentů horní části těla u elitních hráčů golfu, které ovlivňují rychlost hlavy hole při kontaktu s míčkem. Zvolené kinematické parametry (rotace ramen, rotace boků, X-faktor, natažení X-faktoru) a jejich vzájemná časovost k vrcholu nápřahu mají vliv na rychlost hlavy hole v okamžiku kontaktu hlavy hole s míčkem a tím na výslednou délku odpalu.

\section{METODIKA}

Výzkumný soubor tvořilo pět elitních hráčů golfu (věk $31,8 \pm 5,5$ let; výška 1,86 $\pm 0,05$ m; hmotnost $87,0 \pm$ $8,2 \mathrm{~kg}$ ) pravidelně se účastnících profesionálních turnajů v České republice i zahraničí.

Pro určení kinematických parametrů byla využita 3D kinematická analýza (Allard, Stokes, \& Blanchi, 1995) poskytující řadu kvantitativních kinematických parametrů golfového švihu, které je možné využít jako podpůrnou metodu pro deskripci parametrů ovlivňujících výkon při švihu (Hume et al., 2005). Pro utvoření modelu horní části těla (Obr. 1) a hodnocení jejich polohy, úhlových změn mezi segmenty a změny rychlosti v celém průběhu golfového švihu, bylo použito šest aktivních bodů umístěných na těle probanda a na holi (Tab. 1). Aktivní body byly snímány frekvencí $200 \mathrm{~Hz}$ čtyřmi jednotkami cx1 3D kinematického analyzátoru CODA Motion System (Charmwood Dynamics Limited, Leicestershire, England). Testování probíhalo v laboratorních podmínkách (obr. 3), kde každý hráč odehrál 10 úderů z umělé trávy a vlastní holí (železo 7), do ochranné sítě vzdálené 3.5 m od místa odpalování míčku. Hráči byli instruováni k odehrání úderů na vzdálenost, pro kterou běžně používají železo č. 7 při turnaji (bez výškového rozdílu mezi chodidly a jamkovištěm, míčkem ležícím na nízko sekané ploše a v přivětivých klimatických podmínkách $-20-25^{\circ}$ Celsia, bezvětří). 


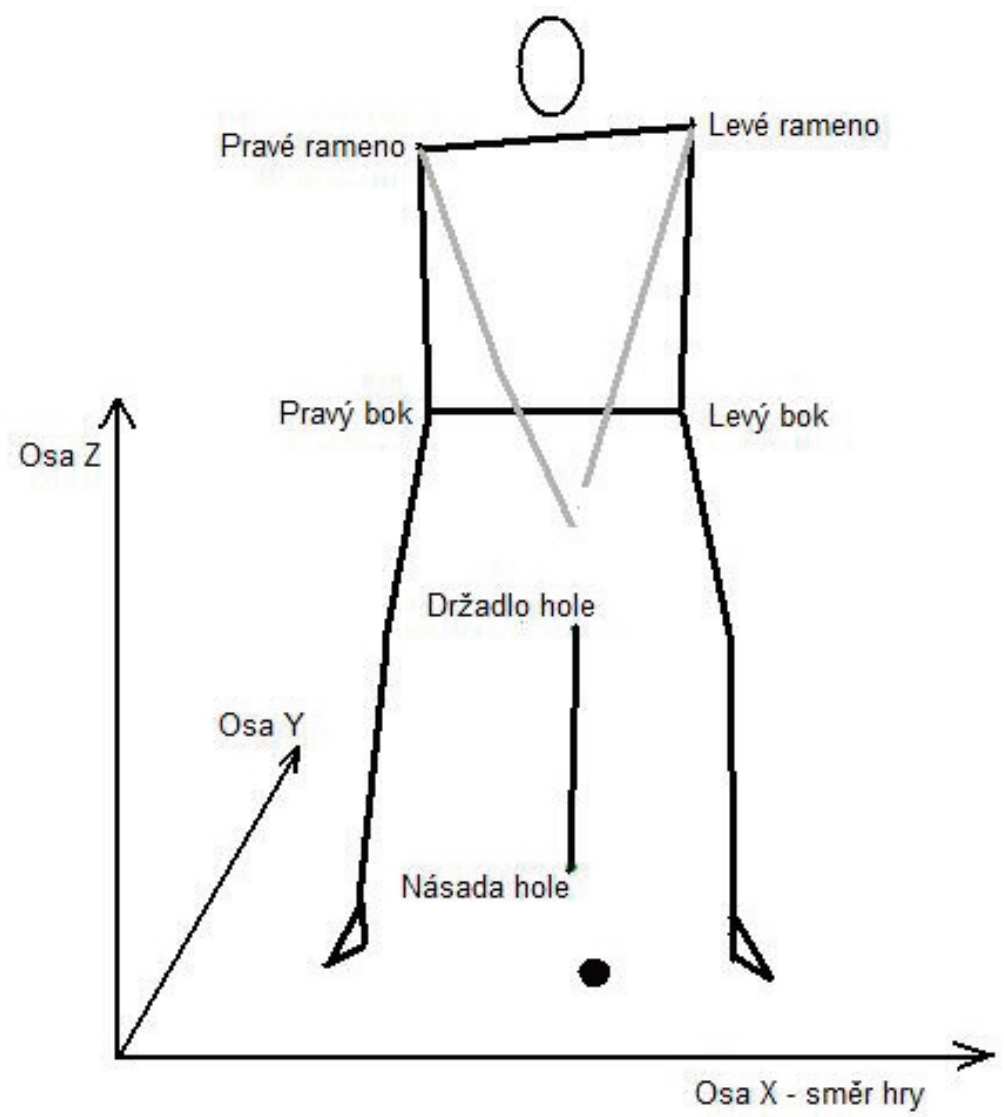

Obr. 1. Model hráče a osový systém použitý při měrení

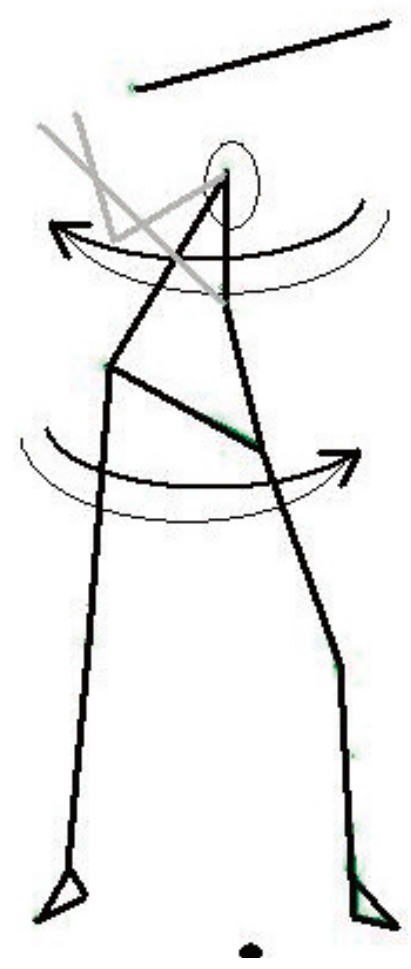

Obr. 2. Začátek švihu k míči začíná pohybem boků, zatímco ramena ještě pokračují v nápřahu. 
Tab. 1. Anatomické umistěni aktivních bodů na těle probanda a na holi

\begin{tabular}{|l|l|l|l}
\hline \multicolumn{2}{l}{ Umístění aktivních bodủ systému CODA Motion System } & \\
\hline Sledovaný parametr & Charakteristika & Aktivní body & Anatomické umístění bodů \\
\hline Poloha ramen & Úhel spojnice aktivních bodů & Levé rameno & Levý acromion process \\
\hline & umístěných na ramenou k ose X & Pravé rameno & Pravý acromion process \\
\hline Poloha boků & Úhel spojnice aktivních bodů & Levý bok & Levý anterior superior illiac spine \\
\cline { 2 - 4 } & umístěných na bocích k ose X & Pravý bok & Pravý anterior superior illiac spine \\
\hline Poloha hole & Určena jako spojnice aktivních bodů umístěných & Rukojet' & Na spodní hraně rukojeti \\
\cline { 2 - 3 } & na holi & Násada & $0.2 \mathrm{~m}$ od spodní hrany hlavy hole \\
\hline Osa X & Určená jako směr hry a znázorněná na podložce & Zadána do koordinačního systému snímacich jednotek cx1 \\
\hline
\end{tabular}

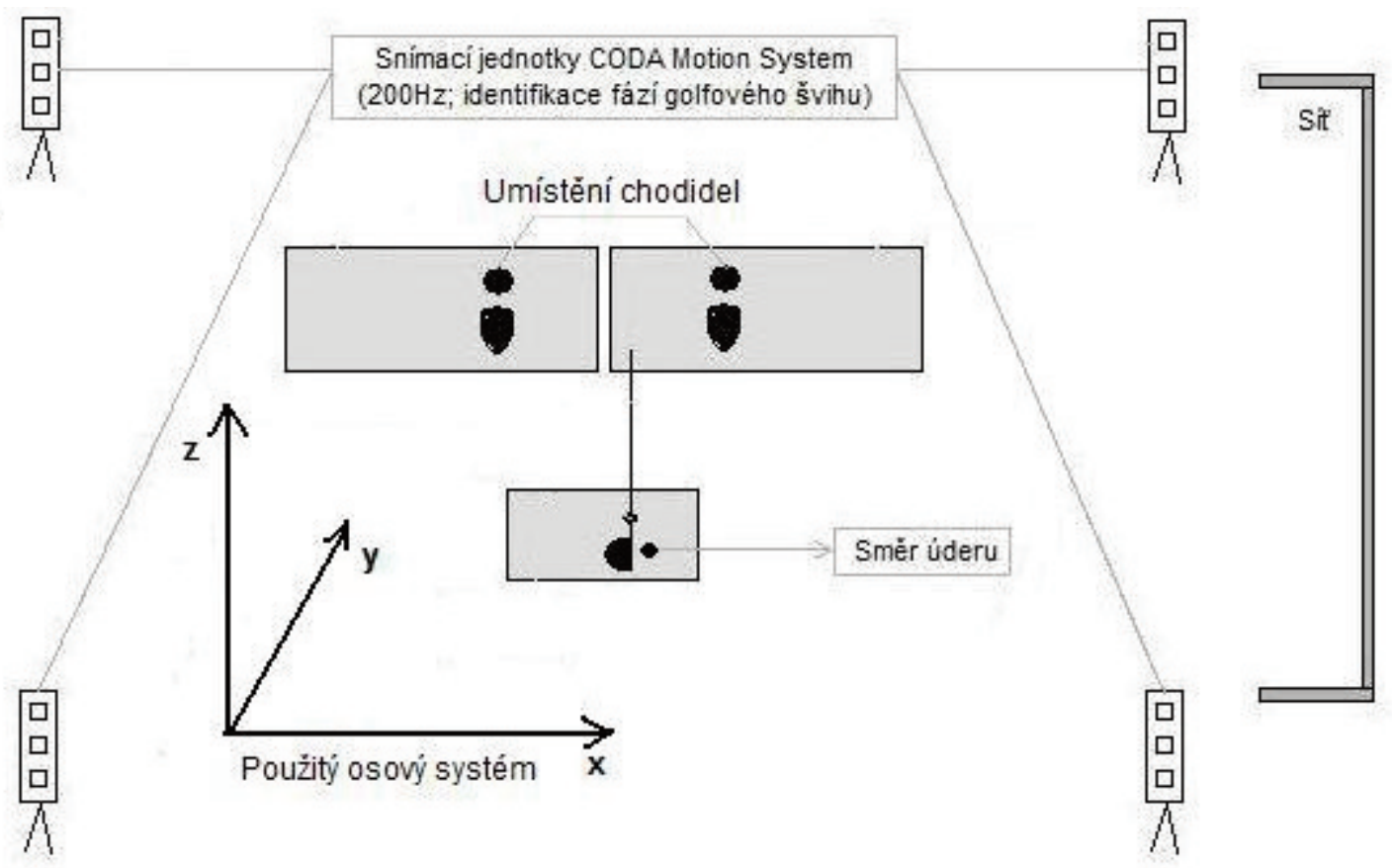

Obr. 3. Laboratorni nastavení a osový systém užitý při testování

Poloha ramen byla určena jako úhel mezi spojnicí bodů umístěných na levém a pravém rameni a osou X. Poloha boků byla určena jako úhel mezi spojnicí bodů umístěných na levém a pravém boku a osou X. Osa X byla definována jako směr hry hráče a znázorněna na podlaze pro určení požadovaného směru hry. Rychlost hole v okamžiku kontaktu s míčkem byla charakterizována rychlostí aktivního bodu umístěného $0.2 \mathrm{~m}$ nad hlavou hole. Přesnost rány nebyla v této studii brána v úvahu, nebot' všichni hráči sledované výkonnostní úrovně mají vysokou opakovatelnost všech úderů. Parametr „,natažení X-faktoru“ byl vypočítán jako časový rozdíl mezi okamžikem maximálního otočení boků a vrcholem nápřahu, kdy pohybem boků začíná švih k míči zatímco ramena pokračují v nápřahu (Obr. 2). Vrchol nápřahu je určen jako okamžik přechodu golfové hole z nápřahu do švihu (Myers et al., 2008).

3D prostorové souřadnice určující polohu bodů byly zpracovány v softwaru CODA Motion a již jako výsledné hodnoty sledovaných parametrů byly exportovány v podobě textového souboru do softwaru Microsoft Office Excel 2003, který byl použit pro jejich zpracování. Ke statistickému zpracování výzkumných údajů jsme použili metody deskriptivní a vztahové analýzy. Pro vyjádření míry polohy jsme použili aritmetický průměr a pro vyjádření míry variability směrodatnou odchylku. Pro vyjádření interindividuální stability provedení byl použit variační koeficient, tradičně využívaný pro hodnocení variability provedení pohybu (Heiderscheit, 2000). Pro statistické hodnocení vztahu mezi kinematickými a časovými parametry a rychlosti hlavy hole byl použit Pearsonův korelační koeficient vypočítaný ve statistickém programu SPSS IBM® verze 20. Pro posouzení signifikantnosti vztahu mezi průměry byla zvolena hladina $\alpha=0,01$. 


\section{VÝSLEDKY}

Přehled sledovaných parametrů a základní statistické údaje jsou uvedeny v Tabulce 2. Švih k míči u námi sledované skupiny elitních hráčů golfu začínal změnou rotačního pohybu boků, který byl následován rotačním pohybem horní části těla až po dosažení okamžiku vrchol nápřahu. Časový rozdíl mezi těmito okamžiky, tedy délka fáze natažení X-faktoru (SXFak), byl průměrně $0.08 \mathrm{~s}(\mathrm{SD}=0,02)$. V průběhu nápřahu se ramena otáčela dále než boky a průměrný rozdíl mezi těmito hodnotami, označovaný jako X-faktor, byl $60,37^{\circ}\left(\mathrm{SD}=6.78^{\circ}\right)$. Průměrná rychlost hole, vyjádřená jako rychlost bodu umístěného $0,2 \mathrm{~m}$ nad spodní hranou hlavy hole, byla $24,37 \mathrm{~m} / \mathrm{s}(\mathrm{SD}=1,04)$.

Stabilita provedení golfového švihu byla posuzována pomocí variačního koeficientu (VK) uvedeného v Tabulce 1 . U dvou parametrů, maximální otočení ramen $(\mathrm{VK}=4,32 \%)$ a rychlost hlavy hole $(\mathrm{VK}=4,26 \%)$, byla identifikována vysoká stabilita provedení. U ostatních parametrů nebyla stabilita provedení na tak vysoké úrovni.

Vztahová analýza mezi jednotlivými kinematickými parametry (Tabulka 3) ukazuje vysoký vztah mezi maximálním otočením boků (Bmax) a ramen (Rmax) v průběhu nápřahu. Byl nalezen také výrazný opačný vztah mezi Bmax a maximální hodnotou X-faktoru (Xmax), tj. čím méně se boky otáčejí v průběhu nápřahu, tím větší je X-faktor. Vztahová analýza provedená u všech pokusů a hráčů ukázala vysoký vztah mezi rychlostí hlavy hole v okamžiku kontaktu s míčkem (RH) a natažením X-Faktoru (SXFak). Při provedení vztahové analýzy mezi RH a SXFak u jednotlivých hráčů se však vysoký vztah mezi těmito parametry (Tabulka 4) neprojevil u žádného hráče. Graf 1 znázorňuje vztah mezi rychlostí hlavy hole v impaktu a natažením X-faktoru u jednotlivých pokusů všech hráčů.

Tab. 2. Přehled sledovaných parametrů a základni statistické vyhodnocení

\begin{tabular}{lcccccc}
\hline Elitni hrác̄i golfu (n=5) & Rozsah & Minimum & Maximum & Prümēr & $\begin{array}{c}\text { Smērodatná } \\
\text { odchylka }\end{array}$ & $\begin{array}{c}\text { Variac̄ní } \\
\text { koeficient }\end{array}$ \\
\hline SXFak & 0.08 & 0.04 & 0.12 & 0.08 & 0.02 & 25.18 \\
Rmax & 16.19 & 90.37 & 106.56 & 99.80 & 4.31 & 4.32 \\
Bmax & 25.89 & 28.43 & 54.32 & 42.68 & 8.20 & 19.20 \\
Xmax & 22.25 & 47.45 & 69.70 & 60.37 & 6.78 & 11.24 \\
RH & 5.34 & 21.79 & 27.13 & 24.37 & 1.04 & 4.26 \\
\hline
\end{tabular}

Tab. 3. Vztahová analýza mezi jednotlivými kinematickými parametry $(\alpha=0.01)$

\begin{tabular}{|c|c|c|c|c|c|c|}
\hline \multicolumn{2}{|c|}{ Elitní hráči golfu (N=5) } & \multirow{2}{*}{$\begin{array}{r}\text { sXFak } \\
1\end{array}$} & \multirow[t]{2}{*}{$R \max$} & \multirow[t]{2}{*}{$B \max$} & \multirow[t]{2}{*}{$X \max$} & \multirow[t]{2}{*}{$\mathbf{R H}$} \\
\hline SXFak & Pearson Correlation & & & & & \\
\hline & Sig. (2-tailed) & & & & & \\
\hline \multirow[t]{2}{*}{$\mathbf{R m a x}$} & Pearson Correlation & $.561^{*}$ & 1 & & & \\
\hline & Sig. (2-tailed) & .000 & & & & \\
\hline \multirow[t]{2}{*}{$B \max$} & Pearson Correlation & $.527^{*+}$ & $.787^{*}$ & 1 & & \\
\hline & Sig. (2-tailed) & .000 & .000 & & & \\
\hline \multirow[t]{2}{*}{$X_{\max }$} & Pearson Correlation & -.174 & -.177 & $-.720^{*}$ & 1 & \\
\hline & Sig. (2-tailed) & .284 & .273 & .000 & & \\
\hline \multirow[t]{2}{*}{$\mathbf{R H}$} & Pearson Correlation & .506 & .288 & .044 & .304 & \\
\hline & Sig. (2-tailed) & .001 & .071 & .789 & .057 & \\
\hline
\end{tabular}

Tab. 4. Vztahová analýza mezi natažením X-faktoru a rychlostí hlavy hole v okamžiku kontaktu s míčkem u jednotlivých hráčů

\begin{tabular}{llrrrrr}
\hline & & & \multicolumn{3}{c}{ SXFak } & \\
& & Hrác 1 & Hrác 2 & Hrác 3 & Hrác 4 & Hrác 5 \\
\hline RH & Pearson Correlation & -.215 & .133 & .434 & -.085 & .6 \\
& Sig. (2-tailed) & .608 & .754 & .283 & .842 & .1 \\
\hline
\end{tabular}


Graf 1. Vztah mezi natažením X-faktoru (SXFak) a rychlostí hlavy hole při kontaktu s mícem (RH) u jednotlivých pokusů všech hráčů

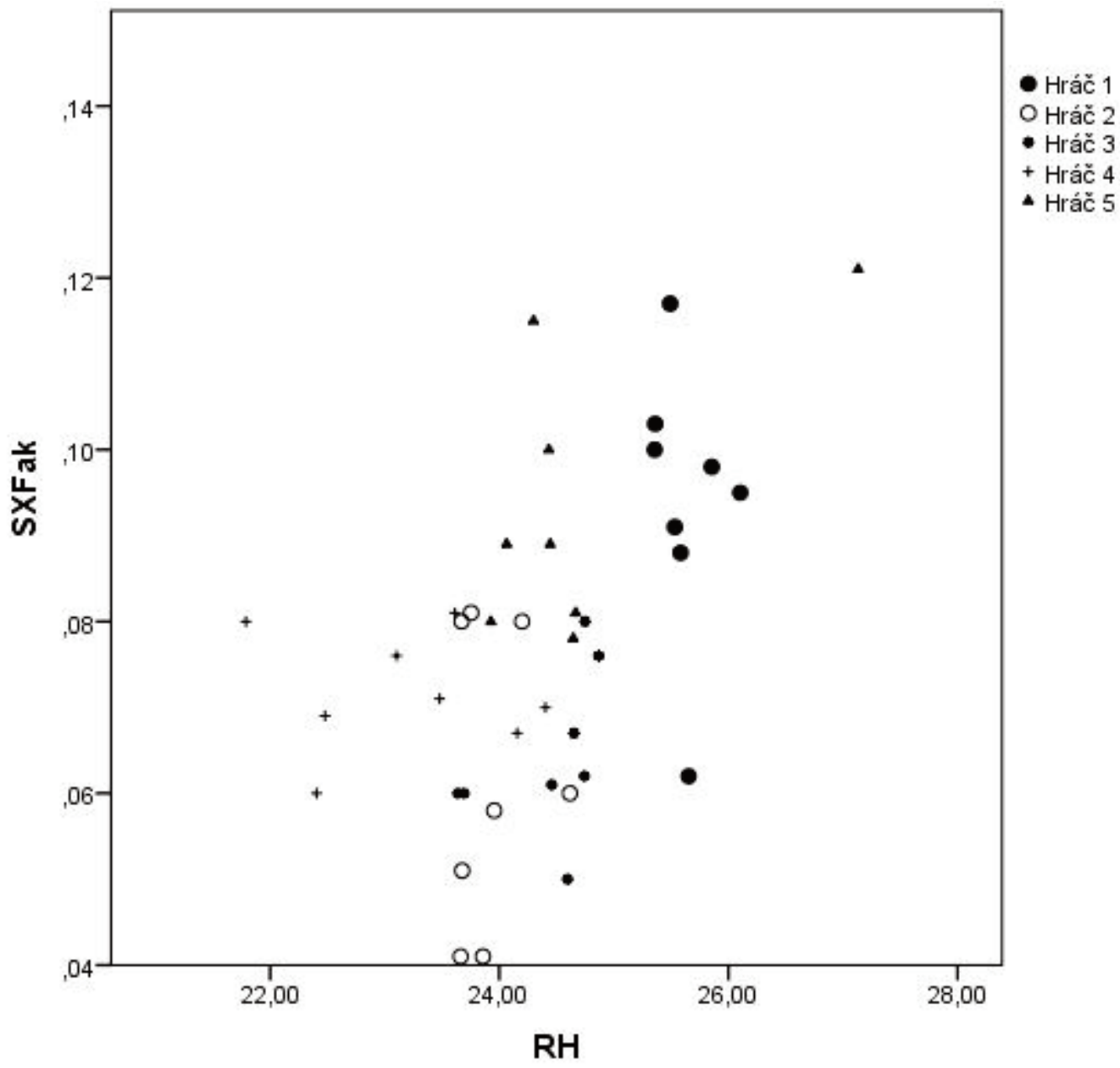

\section{DISKUSE}

Tato studie se zabývala kinematickými parametry pohybu horní části těla v průběhu golfového švihu u elitních hráčů golfu a jejich vztahem k rychlosti hlavy hole v okamžiku kontaktu s míčkem.

Fáze švih $\mathrm{k}$ míči začínala u námi sledovaných hráčů rotačním pohybem pánve směrem $\mathrm{k}$ cíli, následovaném dalšími segmenty horní části těla až k okamžiku vrchol nápřahu (Tab. 1), tato fáze trvala v průměru $0,08 \mathrm{~s}$. Již dříve realizované studie zjistily, že švih k míči začíná pohybem pánve směrem k cíli, který maximalizuje X-faktor v počátcích švihu k míči (Adlington, 1996; Burden, Grimshaw, \& Wallace, 1998; Hume et al., 2005). Cheetham et al. (2000) ve své studii prokázali, že natažení X-faktoru (Stretch X-factor), které ovlivňuje velikost X-faktoru v počáteční fázi švihu $\mathrm{k}$ míči, má dokonce větší vliv na rychlost hlavy hole než X-faktor v okamžiku vrcholu nápřahu. Bylo také prokázáno, že boky jsou vedoucím segmentem pohybu při švihu k míči až k okamžiku impaktu, kdy jsou ramena téměř paralelně s požadovaným směrem hry (Meister et al., 2011).

Dřívější studie prokázaly vysoký vztah mezi maximálním otočením ramen, boků a X-faktoru a rychlostí hlavy hole (případně rychlostí míčku po odpalu) u profesionálních hráčů golfu i hráčů s nízkým hendikepem (Meister et al., 2011; Chu, Sell, \& Lephart, 2010; Meister et al., 2006). Žádná dosavadní studie se však zatím nezabývala vlivem časového rozdílu mezi maximálním otočením boků v průběhu nápřahu a vrcholem nápřahu, tedy délkou fáze natažení X-faktoru, na rychlost hlavy hole v okamžiku kontaktu s míčkem. Časový rozdíl mezi maximálním otočením ramen a vrcholem nápřahu (SXFak) má u námi sledované skupiny elitním hráčů golfu 
vysoký vztah k rychlosti hole v okamžiku impaktu $(0,506, \alpha=0.01 ;$ Tab. 2). Avšak při vztahové analýze mezi SXfak a RH separátně u jednotlivých hráčů (Tab. 3) se tato skutečnost nepotvrdila. Např́klad u hráče 1 můžeme pozorovat (Graf 1) různé hodnoty u parametru SXFak i při vysoké stabilitě rychlosti hole, což je cílem golfového švihu. Variabilitou provedení při dosahování stejného cíle, v golfu konzistentního odpalu, se zabývala studie Langdown, Bridge, and Li (2011) a uvádí, že variabilitou provedení při golfovém švihu rozumíme změny v kinematice a kinetice u jednotlivých pokusů při dosahování stejného cíle. To může být způsobeno vzájemnou polohou dalších segmentů horní části těla, zejména pak vzájemnou polohou ramen, paží a golfové hole, v průběhu golfového švihu. Např́klad Li, Dunn, Betzler, and Shan (2006) se zabývali vzájemným působením paží a golfové hole a jejich vzájemným vztahem ke kontrole pohybu u jednotlivých hráčů a zjistili rozdílné strategie kontroly pohybu mezi probandy.

Stabilita provedení, vyjádřená variačním koeficientem (VK), u parametrů maximální hodnota rotace ramen $\mathrm{v}$ průběhu nápřahu $(\mathrm{VK}=4,32 \%)$ a rychlost hlavy hole $\mathrm{v}$ okamžiku kontaktu hlavy hole s míčkem $(\mathrm{VK}=4,26 \%)$ byla u námi sledovaných hráčů velmi vysoká a odpovídá výsledkům předešlých studií (Adlington 1996; Burden et al. 1998, Grimshaw \& Burden, 2000; Wheat, Vernon, \& Milner, 2007), které však také prokázaly vysokou stabilitu provedení u maximálního otočení boků a X-faktoru, což se v naší studii nepotvrdilo.

Předešlé studie uvádějí maximální rychlost hole nebo rychlost hole v impaktu mezi $33 \mathrm{až} 37 \mathrm{~m} / \mathrm{s}$ (Fradkin, Sherman, \& Finch, 2004; Hume et al. 2005; Meister et al. 2011). Naši hráči do tohoto rozpětí nespadají (24.37 $\pm 1.04 \mathrm{~m} / \mathrm{s}$ ), což je na jednu stranu způsobeno skutečností, že v naší studii byla použita hůl určená pro kratší odpaly (železo č. 7) než při uvedených studiích (Driver, železo č. 5), a také faktem, že rychlost hole je v naší studii vyjádřena jako rychlost bodu umístěného $0,2 \mathrm{~m}$ nad hlavou hole. Uvážíme-li konstantní úhlovou rychlost, tak delší hůl, případně bod umístěný dále (blíže $\mathrm{k}$ hlavě hole), povede $\mathrm{k}$ vyšší zaznamenané rychlosti hole při švihu.

Možným limitem této studie může být realizace v laboratorních podmínkách, kde jsou reálné výsledky odpalu neznámé. Tato studie byla navržena pro identifikaci vlivu kinematických parametrů pohybu horní části těla na rychlost hlavy hole v impaktu, často uváděné a používané jako indikátor vyvinuté energie v průběhu golfového švihu (Ball \& Best 2007; Fradkin et al. 2004; Nesbit \& McGinnis, 2005; Teu et al. 2006; Meister et al. 2011), avšak ne na aktuální délku odpalu. Následné studie by se měly zaměřit nejen na pohyb těla při golfovém švihu a jeho vztah k rychlosti hole, ale také na kvalitativní parametry odpalu, které mohou být vyjádřeny např́iklad vztahem rychlosti hole při kontaktu s míčkem a rychlostí míčku po odpalu.

\section{ZÁVĚRY}

V naší studii jsme zjistili vysokou interindividuální stabilitu provedení především v parametrech rychlost hlavy hole při kontaktu s míčkem a maximální otočení ramen v nápřahu. Při vztahové analýze sledovaných kinematických parametrů pohybu horní části těla jsme zjistili vysoký vztah mezi maximální rotací boků a ostatními sledovanými parametry (maximální rotace ramen, X-faktor, natažení X-faktoru). To naznačuje důležitost role pohybu boků v celém průběhu golfového švihu. Při vztahové analýze mezi rychlostí hlavy hole v okamžiku kontaktu s míčkem a sledovanými kinematickými parametry pohybu horní části těla byl nalezen vysoký vztah pouze s parametrem natažení X-faktoru. Při vztahové analýze mezi rychlostí hole při kontaktu s míčkem a natažením X-faktoru provedené u jednotlivých hráčů nebyl u žádného z nich vztah prokázán. Hráči byli schopni dosahovat stabilní rychlosti hole při kontaktu s míčkem, ačkoliv nevykazovali stejnou stabilitu u parametru natažení X-faktoru. Lze tedy předpokládat, že na stabilitu provedení rychlosti hole při kontaktu s míčem mají u jednotlivých hráčů vliv ostatní parametry pohybu horní části těla, zejména vzájemné polohy ramen, paží a golfové hole. 


\section{LITERATURA}

Adlington, G. S. (1996). Proper swing technique and biomechanics of golf. Clinics in Sports Medicine, 15(1), 9-26.

Allard, P., Stokes, I. A. F., \& Blanchi, J.-P. (1995). Three-Dimensional Analysis of Human Movement. Champaign: Human Kinetics.

Ball, K., \& Best, R. (2007). Different centre of pressure patterns within the golf stroke I: Cluster analysis. Journal of Sports Sciences, 25(7), 757-770.

Bechler, J. R., Jobe, F. V., Pink, M., Perry, J., \& Ruwe, P. A. (1995). Electromyographic Analysis of the Hip and Knee During the Golf Swing. Clinical Journal of Sport Medicine 5(3), 162-166.

Burden, A. M., Grimshaw, P. N., \& Wallace, E. S. (1998). Hip and shoulder rotations during the golf swing of sub-10 handicap players. Journal of Sports Sciences, 16(2), 165-176.

Cheetham, P. J., Martin, P. E., Mottram, R. E., \& Laurent, B. F. S. (2000). The importance of stretching the X Factor in the golf downswing. Paper presented at the International Congress on Sport Science Medicine and Physical Education, Brisbane, Australia.

Chu, Y., Sell, T. C., \& Lephart, S. M. (2010). The relationship between biomechanical variables and driving performance during the golf swing. Journal of Sports Sciences, 28(11), 1251-1259.

Cochran, A. J., \& Stobbs, J. (1996). The Search for the Perfect Swing: The Proven Scientific Approach to Fundamentally Improve Your Game: Triumph Books.

Cooper, M. A. J., \& Mather, J. S. B. (1994). Categorization of golf swings. Paper presented at the Science and Golf II: Proceedings of the World Scientific Congress of golf.

Grimshaw, P. N., \& Burden, A. M. (2000). Case report: Reduction of low back pain in professional golfer. Medicine and Science in Sports and Exercise, 32(10), 1667-1673.

Heiderscheit, B. C. (2000). Movement variability as a clinical measure for locomotion. Journal of Applied Biomechanics, 16, 419-427.

Hume, P. A., Keogh, J., \& Reid, D. (2005). The role of biomechanics in maximizing distance and accuracy of golf shots. Sports Medicine, 35(5), 429-449.

Langdown, B. L., Bridge, M., \& Li, F.-X. (2012). Movement variability in the golf swing. Sports Biomechanics, $11(2), 273-287$.

Li, X., Dunn, B., Betzler, N., \& Shan, G. (2006). Golfer-club interaction during swing and its influences on motor control strategies employed by advanced golfers. Paper presented at the XXIV ISBS Symposium, Salzburg - Austria.

Lindsay, D., \& Horton, J. (2002). Comparison of spine motion in elite golfers with and without low back pain. Journal of Sports Sciences, 20(8), 599-605.

McLean, J. (1992). Widen the gap. Golf Magazine, 34(12), 49.

Meister, D., Schroeder, J., Butler, E., Twist, K., Ladd, A., \& Rose, J. (2006). Kinematic and Kinetic Analysis of the elite golf swing. Paper presented at the 24. Annual International Symposium on Biomechanics in Sports, Salzburg.

Meister, D. W., Ladd, A. L., Butler, E. E., Zhao, B., Rogers, A. P., Ray, C. J., et al. (2011). Rotational Biomechanics of the Elite Golf Swing: Benchmarks for Amateurs. Journal of Applied Biomechanics, 27, 242-251.

Myers, J., Lephart, S., Tsai, Y., Sell, T., Smoliga, J., \& Jolly, J. (2008). The role of upper torso and pelvis rotation in driving performance during the golf swing. Journal of Sports Sciences, 26(181-188).

Nesbit, S., \& McGinnis, R. (2009). Kinematic analyses of the golf swing hub path and its role in golfer/club kinetic transfer. Journal of Sports Science and Medicine (8), 235-246.

Teu, K. K., Kim, W., Fuss, F. K., \& Tan, J. (2006). The analysis of golf swing as a kinematic chain using dual Euler angle algorithm. Journal of Biomechanics, 39(7), 1227-1238.

Wheat, J. S., Vernon, T., \& Milner, C. E. (2007). The measurement of upper body alignment during the golf drive. Journal of Sports Sciences, 25(7), 749-755.

Zheng, N., Barrentine, S. W., Fleisig, G. S., \& Andrews, J. R. (2008). Kinematic analysis of swing in Pro and amateur golfers. International Journal of Sports Medicine, 29(6), 487-493. 